\title{
T Lymphoblastic Leukemia/Lymphoma
}

National Cancer Institute

\section{Source}

National Cancer Institute. I Lymphoblastic Leukemia/Lymphoma. NCI Thesaurus. Code C8694.

A neoplasm of lymphoblasts committed to the T-cell lineage, typically composed of small to medium-sized blast cells. When the neoplasm involves predominantly the bone marrow and the peripheral blood, it is called T acute lymphoblastic leukemia. When it involves nodal or extranodal sites it is called T lymphoblastic lymphoma. (WHO, 2001) 